\title{
THE ACTIVITIES OF CONSUMERS' ORGANIZATIONS
}

\author{
JAMES F. CORBETT*
}

Someone once said that if two people with the same idea get together in America, the result is an ORGANIZATION. Run your finger down the list of names of associations and societies in any almanac or directory and you will find Eagles, Owls, Elks and Moose, Dragons and Druids, National Associations of Manufacturers of everything from abacuses to zithers, but you will find very few groups whose work lies in the protection of the consumer or the advancement of his interests. Consumers in America ( $120,000,000$ of them) are notoriously unorganized. This places them in a tremendously disadvantageous position in a democracy such as ours, where legislation is enacted in response to the demands of articulate groups capable of exerting economic and political pressure where it is most needed. It is estimated that there are well over 1000 trade associations ever active in Washington to give force and directness to the opinions and wishes of business. Yet there is probably no economic group in the country which is less adequately represented in the lobbies of our legislatures than the consumers.

The passage of the Food and Drugs Act in 1906 can be attributed to the efforts of certain public-spirited and fearless friends of the consumer such as the late Dr. Wiley and Professor Ladd, and the self-interest of farmer's organizations rather than to any organized activity on the part of consumers. The timely publication of The Jungle by Upton Sinclair did much to arouse public opinion, while the lobbies of the American Medical Association and the National Association of State Dairy and Food Departments were fighting the stand-patters in Washington. The crusade of the muckrakers against false and fraudulent advertising left a passing impression upon the public, soon to be forgotten as the great "Ballyhoo Age" descended upon us and muckraking was no longer profitable. In 1927 the apathetic public was again aroused when Your Money's Worth by Stuart Chase and F. J. Schlink described the waste of the consumer's dollar which resulted from his ignorance in purchasing goods in the new jungle of competitive advertising and powerful sales pressure, where the skillful

- B.S., r925, College of the City of New York; M.A., I930, New York University. Instructor in economics in a New York City high school. Assisted in the preparation of a prospective syllabus in Vocational Civies for New York City schools. Now engaged in the preparation of a study of consumption problems and their relation to education, and is collaborating on a new high school economics text emphasizing the development of social control. 
presentation of misinformation with the aid of the latest psychology and pseudoscience, was forcing upon him all sorts of shoddy, adulterated and harmful goods at prices which reaped high profits for the producer. Soon a best seller, the book became a target for many bitter attacks by business and advertising men in the popular magazines. An attempt was made to pin the Bolshevik label upon it with the insinuation that the authors were inspired, if not subsidized, by the Third Internationale. One of the authors had previously organized a Consumers' Club to apply technological research to the qualities of foods, drugs, cosmetics, and other products. This organization grew rapidly and in I929 became Consumers' Research, Inc., "a strictly non-profit, non-commercial, research and educational organization which studies and reports on goods and services from the point of view of their selection, purchase, and use by the ultimate consumer, and solely for the ultimate consumer's use and benefit." In four years the membership of subscribers, who pay an annual fee of $\$ 2.00$, has grown from less than I000 to some 45,000 . New quarters where more extensive research facilities can be developed are now located in Washington, N. J.

The activities of Consumers' Research may be classified as (I) Testing and Advisory, (2) Educational, and (3) Legislative.

\section{Testing and Advisory Activities.}

In the four or five Handbooks of Buying which are sent to subscribers each year, several thousand products from alarm clocks to yeast are listed by brand name as recommended or not recommended. This advice is based upon actual test and research data or the authoritative and impartial opinions of governmental and private experts of known integrity. The following is a greatly condensed excerpt from one of the Handbooks and will give an idea of the material presented.

\section{CANNED FRUIT FOR SALADS}

Cans of mixed fruit for salads usually contain some discolored or mushy fruit, the individual taste of the various pieces is largely lost, and the bulk of the mixture usually consists of the cheapest fruit. Maraschino cherries, which are not recommended . . . are used. . . .

(A) Recommended

Commonwealth (dist. Commonwealth Packing Co., San Francisco) Not all firm, flavor good, 26c per lb. drained fruit.

(B) Intermediate

Del Monte (California Packing Corp.) Several minor defects. Flavor good, rgc per lb. drained fruit.

(C) Not Recommended

Kingko (King's County Packing Co., Oakland, Calif.) Some of fruit broken or mushy. Color and flavor good. 2ic per lb. drained fruit.

Libby's (Libby, McNeill \& Libby) Mushy pale fruit. Good flavor. 3IC per lb. drained fruit. 
Consumers' Research data shows that in many cases prices vary inversely with quality, and that, strange as it may seem to some people, prominent brands are often inferior. The Handbooks give authoritative information about diet, vitamins, canned and packaged foods, adulteration or false advertising of foods, drugs, antiseptics and cosmetics. In every case brand names are given since information of this sort without knowledge of the names of the products involved is only of academic value and can not be put to practical use by the consumer. The subscriber is pledged to treat most of the information regarding branded products as confidential, since the legal problem of possible libel or damage suits arising from criticism of such products has not yet been solved. However, Consumers' Research is now publishing a non-confidential bulletin in which such well-known products as Ambrosia, Clorox and Zonite Antiseptics, Vapex, Pebeco Toothpaste and Pepsodent Antiseptic are freely discussed and criticized.

\section{Educational Activities.}

The very nature of the confidential advisory service keeps the subscriber informed of the qualities and prices of goods, and the manner in which he can get more for his income. In the non-confidential bulletins, news of interest to the consumer is published. For example, in recent issues: a scientific discussion of athlete's foot, with the advice that proprietary drugs of secret composition such as Absorbine, Jr., Emerald Oil, and W.F. should not be used: a reprint from the Journal of the American Medical Association exposing the deception in the pseudo-scientific advertising of Scot Tissue. The General Bulletin has kept the consumer acquainted with the activity, and especially, lack of activity, of governmental agencies such as the Bureau of Standards, the Federal Trade Commission, and the Bureau of Mines, in serving the consumer-taxpayer. Laxity on the part of the Department of Agriculture and the Food and Drug Administration in actively enforcing the laws for the protection of the consumer has been severely criticized. Much of this information which was long familiar to Consumers' Research subscribers, was presented in a recent book by two members of the organization.

This book, 100,000,000 Guinea Pigs, by Arthur Kallet and F. J. Schlink, has been a best seller for over six months. A large part of the public became familiar for the first time with the need for revising the food and drug laws and rebuilding the administrative machinery so that effective enforcement might be assured. In this book names were named and the apparently "reformed" drug, cosmetic, and food industries were brought out into the open, revealing fruits and vegetables contaminated with lead and arsenic from insecticide residues; poisonous cosmetics; worthless antiseptics; inert ergot and sub-standard ether; emasculation of the protective features of the Food and Drugs Act for the benefit of food and drug purveyors.

\section{Legislative Activities.}

Although Consumers' Research cannot support a lobby in the state capitols or at Washington, it has long maintained that only through effective organization can 
the consumer secure protection. "Producers Organize-Consumers Must." Consumers' Research keeps in touch with legislators who are sympathetic with the consumer's interest and supplies them with needed data to remedy existing legislation, strengthen administrative procedure, or combat bills or rulings which are opposed to the consumer's welfare. Students of the food and drug problem and trade papers in the industries attribute the present widespread demand for sweeping changes in the Food and Drugs Act, and for a radical change in the administration of the law, to the Bulletins and activities of Consumers' Research and particularly to the public indignation which has followed the exposures in 100,000,000 Guinea Pigs. A barrage of criticism has been continuously laid down against the rulings and methods of the Food and Drug Administration which has been sympathetic toward the big business viewpoint which, in meeting the stockholders' demand for dividends, too often places profits above the health or welfare of the trusting consumer. Consumers' Research has long advocated administration of the laws by scientists and technologists like the late Dr. Wiley, rather than by lawyer-politicians; supervision of advertising which now runs hog-wild and scotfree; a system of frank and full publicity for all aspects of food, drugs, and cosmetic regulation. This organization is now sponsoring new legislation in New York State and, as the Chairman of the Senate Committee on Public Health stated to the writer, is the only group to show any interest in the movement for better food and drug laws.

Consumers' Research, in I932, helped oppose the passage of the Capper-Kelly Bill $^{1}$ which would have enabled manufacturers to fix the prices at which their products could be sold at retail. The only other organization representing the consumer at the hearings was the American Home Economics Association. This organization of ro,000 teachers of home economics was founded in 1908 and has been largely responsible for the advance in home economics education which has taken place in the United States. The Journal of Home Economics which the Association publishes, has never been critical of the Food and Drug Administration and has often carried articles which are manifestly propaganda of the Administration itself or of food manufacturers. In the field of textiles and household equipment, however, the Association has taken a more aggressive stand. In coopperation with the American Standard Association, which is dominated by business interests, an attempt was made to set up quality standards for, and require informative labeling on such products as blankets, sheets, silk, and refrigerators. The opposition of the manufacturing representatives who dominated the conferences, was strong enough to sabotage the program, and the consumer can read the labels today and be just as ignorant as he ever was regarding the quality of the merchandise.

Much has been written in the Journal about improving school courses of study, in home economics, but today cooking and sewing still predominate in the curriculum. With business men on boards of education clamoring for retrenchment,

\footnotetext{
₹ g2nd. Cong., rst. Sess, S. 97 (1932).
} 
and the elimination of what they are pleased to call the "fads and frills," home economics teachers are having a hard enough time holding on to their jobs, and little is being done to furnish useful buying information in the schools. Some of the research conducted by home economists in such diet problems as vitamins, has been useful, but it is very soon perverted into misinformation by the advertisers of drugs and food products who often employ home-economists to achieve this end. Much of the research is devoted to the solution of such burning problems as the "Factors Controlling Internal Temperatures of Butter Cakes During Baking."

The National Consumers League has for its purpose the protection of the worker through the coöperation of the consumer. Although it participated in the great crusade of $\mathrm{x} 906$, this organization has been more prominent in securing shorter hours and decent working conditions for women and children. The Coöperative League of the U.S. A. hopes to protect the consumer through a reorganization of society and the "ownership of industry by voluntary associations, consisting of consumers, run by consumers, functioning for consumers." Through their national periodical Coöperation they keep their members informed of the difficulties of the consumer in the present market, but like the Consumers' League, they have not taken any active part in establishing standards for foods and drugs or sponsoring and demanding increased protection through legislation.

One might expect that women's organizations would be particularly active in lobbying for more adequate protection of consumers, but their work has not been very effective in this field. Nearly thirty years ago, energetic Miss Alice Lakey swung the forces of the General Federation of Women's Clubs into line to fight for the pure food lobby. Since then, with an estimated membership of over two million they have carried on a modest program, in coöperation with the American Home Economics Association and the Bureau of Home Economics, to encourage its members to study the problem of household purchasing. The total result of such programs seems to be a realization on the part of these women that it is almost hopeless to buy intelligently with the present information available to the housewife. The Association of University Women, with a present membership of about 40,000 is also helping to spread information on consumers' problems through its Journal and other publications. An organization which might be particularly effective if it ever decided to marshal its strength on the side of the consumer, is the Women's Joint Congressional Committee. Since 1923 it has been composed of seventeen national women's organizations. In I923 they secured the passage of new legislation regulating interstate and foreign commerce in livestock and other agricultural or dairy products, and prohibiting commerce in "filled" or adulterated milk. Their interest, however, has been largely in other fields, such as women's rights, child welfare, and social hygiene.

It is difficult for such consumer organizations to become an effective pressure group, either as a legislative lobby, or a propaganda agency. It is next to impossible 
to secure a large endowment in America for any work which will conflict with the wishes of organized business. In the case of women's organizations, most of their funds come from members or friends whose interests must be on the producer's side, although it is of course quite possible that one of these days a philanthropist may appear who is disinterested enough to leave part of a fortune for work to be carried on in the interest of consumers. In addition, the members of women's clubs or associations often find that their own sympathies can not be wholeheartedly with the consumer. The economic interests of other members of their families, or of the group itself, will promptly inhibit any militant impulse to attack local or national business too strenuously. There are strong social as well as economic bonds to be considered-and houses divided against themselves make poor lobbies.

As for propaganda: public opinion is controlled largely through the press and the radio, and these are not anxious to be too offensive to advertisers. The schools are having their troubles in securing enough money to keep open. Progressive educators may desire to impart information in the class room, but as Professor Lynd very tactfully puts it in Recent Social Trends with scholarly caution and avoidance of controversy: "even . . . adventurous school systems encounter . . . the tactical difficulty of using such data, even when available, in a local community living by competitive merchandising."

If consumers are to get together for their own protection (and they certainly need to today) an organization such as Consumers' Research, Inc., seems to be the most likely type about which the movement can grow. Its integrity has never been questioned by informed people, its steady growth indicates that it is meeting a need which consumers really feel, and its program and policies are practical and militant rather than visionary, weakly liberal, or utopian. The consumer is supposed to be represented in the National Recovery Administration by a Consumers' Advisory Board. The extent to which this board has represented him has been dramatically disclosed by the front page news of the resignation of the famed sociologist, Professor Ogburn, who declared that "the weakest link [in the recovery program] is the provision for protection of consumers," that there was no strong organization represented to fight the consumers' case, and that no adequate attempt has been made to gather facts or establish standards relating to price and quality.

It is apparently time for a strong consumer organization to take a hand in the new deal. The cards must be played with great skill because rooo trade associations consider consumer ignorance and disorganization a vested interest to be retained at all costs.

\footnotetext{
'Iynd, The People as Consumers, 2 Recent Soctax Trends (1932) 857, 882.
} 